\title{
Strategi Penyampaian Informasi Melalui Instagram Dengan Tampilan Infografis (di Kementerian Perdagangan RI)
}

\author{
Edy Juliyanto, Farid Rusdi \\ edy.915150084@stu.untar.ac.id, farid@fikom.untar.ac.id \\ Fakultas Ilmu Komunikasi Universitas Tarumanagara
}

\begin{abstract}
This research is about the use of infographic as an communication medium for delivering information that related to Trading Ministry of Republic Indonesia activity, and shared from Trading Ministry of Republic Indonesia's social media, Instagram. This study used case studies with qualitative approach. This studies using "Medium is The Message" concept theory from Marshall McLuhan, design element theory, and new media. The results and conclusions of this research is the public relation office of Indonesian Trading Ministry have doing a good step by using infographic as their medium for delivering information, it used for attract also make the young generation easily understand the information. Especially, infographic in Indonesian Trading Ministry using Instagram as their application for sharing information which is many young generation using that application. A information from CNN Indonesia, data from Indonesian National Library 2017 reading interest from Indonesian peoples is low, this statement become one of many factors from Indonesian Trading Ministry using Infographics to solve this low reading interest.
\end{abstract}

Keywords: Infographic, medium, content, new media.

\begin{abstract}
Abstrak
Penelitian ini mengenai penggunaan infografis sebagai medium komunikasi dalam menyampaikan informasi, yang berkaitan dengan aktivitas Kementerian Perdagangan RI. Informasi disebarkan melalui media sosial instagram Kementerian Perdagangan RI. Studi ini menggunakan metode studi kasus dengan pendekatan kualitatif. Penelitian ini menggunakan konsep teori "medium is the message" dari Marshall McLuhan, teori elemen desain, dan new media. Hasil penelitian ini yaitu Biro Humas Kementerian Perdagangan RI sudah melakukan langkah yang tepat dalam memilih infografis sebagai medium dalam penyampaian informasinya, untuk menarik perhatian sekaligus memudahkan generasi muda memahami isi pesannya. Terlebih infografis Kementerian Perdagangan RI disebarkan melalui media sosial instagram yang kebanyakan penggunanya adalah generasi muda. Menurut informasi yang dikutip CNN Indonesia dari data Perpustakaan Nasional tahun 2017, minat baca masyarakat Indonesia tergolong rendah, ini menjadi salah satu faktor hadirnya Infografis di media sosial Kementerian Perdagangan RI untuk mengatasi masalah rendahnya minat baca ini.
\end{abstract}

Kata Kunci: Infografis, medium, konten, media baru.

\section{Pendahuluan}

Pada era digital saat ini daring sangat dekat hubungannya dengan semua orang. Ditambah dengan kemajuan teknologi, gawai yang semakin hari semakin canggih membuat semua orang bisa terhubung dengan mudah kepada daring dan dapat melakukan banyak hal dengan gawai atau yang biasa kita kenal sebagai smartphone. Mulai dari berkomunikasi, membaca berita, hingga berbelanja dan berdagang melalui smartphonenya masing-masing. 
Penyajian berita atau informasi kepada khalayak pun sudah banyak mediumnya agar khalayak tertarik dan mudah memahami sebuah informasi yang disampaikan baik dari sebuah portal berita, perusahaan maupun dari lembaga pemerintahan. Beberapa medium penyampaiannya seperti video berdurasi 20 detik, karikatur, grafik, infografis dan masih banyak metode lainnya.

Kementerian Perdagangan Republik Indonesia merupakan sebuah lembaga pemerintah yang sudah bediri sejak 2 September 1945 yang pertamakali bernama Kementerian Kemakmuran dijabat oleh Surachman Tjokrodisurjo, dan sekarang dijabat oleh Enggartiasto Lukita. Kementerian Perdagangan bertugas untuk menyelenggarakan urusan di bidang perdagangan dalam pemerintahan untuk membantu Presiden dalam menyelenggarakan pemerintahan Negara.

Biro Humas Kementerian Perdagangan Republik Indonesia sering menginformasikan banyak hal yang berkaitan dengan Kementerian Perdagangan melalui beberapa akun sosial medianya seperti Facebook, Twitter, Youtube, dan Instagram. Salah satu medium dalam menyampaikan informasi yang sering Biro Humas Kementerian Perdagangan gunakan melalui media sosialnya adalah infografis.

Menurut kamus Oxford, infographic atau dalam bahasa Indonesia yang berarti infografis adalah sebuah representasi atas informasi atau data yang berbentuk grafik atau diagram. (https://en.oxforddictionaries.com/definition/infographic)

Membuat infografis sendiri adalah percampuran antara skill desain, analisis informasi, dan storytelling yang merupakan kunci dari infografis yang maksimal. Infografis adalah representasi visual dari data secara grafis untuk menyampaikan informasi lengkap kepada pembaca agar dapat dipahami dengan lebih mudah, cepat, singkat, dan jelas. Infografis (penulisan yang benar adalah infografis dengan $\mathrm{S}$, bukan infografik dengan K) berasal dari kata Infographics dalam Bahasa Inggris yang merupakan singkatan dari Information dan Graphics. Proses pembuatan infografis disebut data-visualization, information design, atau information architecture. (http://houseofinfographics.com/apa-itu-infografis/)

Faktor pertama pemilihan topik ini adalah tentang rendahnya minat baca. Dilansir dari portal berita CNN Indonesia minat baca masyarakat Indonesia disebut masih rendah bila dibandingkan negara lain. Dari data Perpustakaan Nasional tahun 2017, frekuensi membaca orang Indonesia rata-rata hanya tiga sampai empat kali per minggu. Sementara jumlah buku yang dibaca rata-rata hanya lima hingga sembilan buku per tahun. Saat ini ketertarikan seseorang untuk membaca sangat rendah sekali terlebih jika tulisan tersebut sangat panjang dan mengandung kata-kata yang tidak familiar di masyarakat. Faktor kedua yaitu, media sosial saat ini merupakan hal yang sangat dekat sekali dengan masyarakat dari berbagai golongan (atas, menengah, dan rendah). Banyak informasi yang dapat diakses oleh masyarakat melalui media sosial. (https://www.cnnindonesia.com/gaya-hidup/20180326160959-282-285982/minatbaca-masyarakat-indonesia-masih-rendah)

Medium infografis sering digunakan pada media sosial Instagram oleh Biro Humas Kementerian Perdagangan dalam menyampaikan informasi seperti eksporimpor, edukasi konsumen, hingga kegiatan-kegiatan dari Kementerian Perdagangan juga dikemas dalam medium infografis oleh Biro Humas Kementerian Perdagangan RI. 
Edy Juliyanto, Farid Rusdi: Strategi Penyampaian Informasi Melalui Instagram Dengan Tampilan Indografis (di Kementerian Perdagangan RI)

\section{Metode Penelitian}

Penelitian ini menggunakan pendekatan deskriptif-kualitatif. Penelitian kualitatif merupakan metode penelitian yang berlandaskan pada filsafat positivisme, digunakan untuk meneliti pada kondisi obyek yang alamiah, (sebagai lawannya adalah eksperimen) dimana peneliti adalah sebagai instrumen kunci, pengambilan sampel sumber data dilakukan secara purposive dan snowball, teknik pengumpulan dengan trianggulasi (gabungan), analisis data bersifat induktif-kualitatif, dan hasil penelitian kualitatif lebih menekan makna dari pada generalisasi. (Sugiyono, 2011).

Pada umumnya, penelitian kualitatif deskriptif berupaya keras agar pembahasan mereka lebih cenderung kualitatif daripada kuantitatif, dengan mendekati makna dan ketajaman analisis-logis dan juga dengan cara menjauhi statistik "sejauh-jauhnya", maka kualitatif deskriptif diterima sebagai salah satu tipe penelitian kualitatif. Lebih lanjut, penelitian sosial menggunakan format deskriptif kualitatif bertujuan untuk mengkritik kelemahan penelitian kuantitatif (yang terlalu positivisme), serta juga bertujuan untuk menggambarkan, meringkaskan berbagai kondisi, berbagai situasi, atau berbagai fenomena realitas sosial yang ada di masyarakat yang menjadi objek penelitian, dan berupaya menarik realitas itu ke permukaan sebagai suatu ciri, karakter, sifat, model, tanda, atau gambaran tentang kondisi, situasi, atatupun fenomena tertentu (Bungin, 2011).

Penelitian yang dilakukan penulis menggunakan strategi penelitian studi kasus. Menurut Mulyana (2001:201) peneliti studi kasus berupaya menelaah sebanyak mungkin data tentang subjek yang diteliti. Metode yang biasa digunakan adalah wawancara, riwayat hidup, survei serta data yang terkait dengan kasus tersebut.

Selain itu Lincoln dan Guba menjelaskan penggunaan studi kasus sebagai suatu metode penelitian kualitatif memiliki beberapa keuntungan, yaitu:

1. Studi kasus dapat menyajikan pandangan dari subjek yang diteliti.

2. Studi kasus menyajikan uraian menyeluruh yang mirip dengan pengalaman yang dialami pembaca dalam kehidupan sehari-hari.

3. Studi kasus merupakan sarana efektif yang menunjukan hubungan antara peneliti dengan responden.

4. Studi kasus dapat memberikan uraian mendalam yang diperlukan bagi penilaian atau transferabilitas (Mulyana, 2001:201).

Studi kasus pada penelitian ini, penulis ingin menggungkap penggunaan media Infografis pada media sosial Kementerian Perdagangan mengapa media ini cukup diperhatikan dan dijadikan focus untuk menyampaikan berita atau informasi kepada masyarakat Republik Indonesia.

Berikut beberapa teori yang peneliti gunakan dalam penelitian ini, Medium: Dalam buku Marshall McLuhan yang berjudul The Medium is the Massage (1964), McLuhan beropini bahwa media mempengaruhi publik bukan hanya melalui konten yang tersedia melainkan juga karakteristik dari media itu sendiri. Inti dari teori Marshall McLuhan The medium is the message ini adalah bagaimana publik memahami media, dan efek dari media tersebut mempengaruhi publik itu sendiri.

Infografis: Infografis merupakan sebuah medium baru untuk menyampaikan informasi maupun pesan saat ini. Infografis mengubah data dan teks yang panjang menjadi sebuah medium yang mudah dimengerti dengan kombinasi komponenkomponen visual grafis (gambar atau ilustrasi, warna, tipografi, dan layout). Infografis adalah informasi yang berfokus pada tampilan visual. Dari buku yang berjudul "Infografis: Kedahsyatan Cara Bercerita Visual" (2014) oleh Lankow et al, 
yang beropini bahwa kelebihan dari infografis adalah hasil dari perpaduan komponen visual mampu memudahkan penyampaian informasi menjadi lebih menarik dan mudah dimengerti.

New Media: Media baru adalah revolusi pada ilmu komunikasi dan telah mengubah "keseimbangan kekuatan" dan media kepada khalayak, dalam hal mereka lebih memiliki pilihan untuk memilih dan lebih menggunakan media yang tersedia secara aktif. Komunikasi massa tradisional pada intinya bersifat satu arah, sementara bentuk baru komunikasi secara pokok adalah interaktif. Selain itu media baru juga memiliki dua aspek revolusioner yaitu digitalisasi dan konvergensi. Digitalisasi adalah proses dimana semua teks dapat dikurangi menjadi kode biner dan dapat mengalami proses produksi, distribusi dan penyimpanan yang sama. Konvergensi adalah penggabungan antara tulisan, suara ataupun gambar dari semua media tradisional dengan menggunakan sarana digital bila dibandingkan dengan media tradisional yang menggunakan sarana analog (McQuail, 2011).

Teori Elemen Desain, Gambar dan Ilustrasi: Africa Fanlo (dalam Estrade, 2010:128), ilustrasi adalah gambar yang menjelaskan konsep spesifik untuk menyampaikan informasi. Fungsi penggunaan ilustrasi adalah menciptakan apa yang tidak dapat dilakukan melalui foto, serta dapat menciptakan gambar-gambar yang dapat mewakili suatu karakteristik atau sifat di dalam media. Ilustrasi juga berfungsi untuk memberi gambaran secara jelas tentang sebuah objek dan menjelaskan objek secara terperinci melalui visual.

Warna: Setiap warna memberikan kesan dan identitas tertentu sesuai dengan kondisi sosial pengamatnya. Setiap warna memiliki pengaruh bagi psikologis masing-masing orang. Warna memberi suasana kejiwaan dalam berkomunikasi. Warna dapat menyentuh kepekaan penglihatan sehingga mampu merangsang munculnya rasa baru, sedih, gembira, semangat, dan lain-lain. Secara visual, warna memiliki kekuatan yang mampu memberi respon secara psikologis (Adi Kusrianto, 2007:46-47).

Layout: Layout menurut Gavin Ambrose dan Paul Harris dalam bukunya Basic Design. Layout (2005:108) adalah penyusunan dari elemen-elemen desain yang berhubungan ke dalam sebuah bidang sehingga membentuk susunan artistik. Hal ini bisa juga disebut manajemen bentuk dan bidang. Tujuan utama Layout adalah menampilkan elemen gambar dan teks agar menjadi komunikatif dalam sebuah cara yang dapat memudahkan pembaca menerima informasi yang disajikan.

Tipografi: Tipografi merupakan representasi visual dari sebuah bentuk komunikasi verbal dan merupakan properti visual yang pokok dan efektif. Lewat kandungan nilai fungsional dan nilai estetiknya. Huruf mempunyai potensi untuk menerjemahkan atmosfir yang tersirat dalam sebuah komunikasi verbal yang dituangkan melalui abstraksi bentuk-bentuk visual (Sihombing, 2001:16).

\section{Hasil Temuan dan Diskusi}

Analisis Pemilihan Medium Infografis Sebagai Penyampaian Informasi: Pemilihan infografis sebagai medium dalam penyampaian informasi oleh Kementerian Perdagangan RI dinilai oleh pengamat media sosial dan desain grafis sebagai langkah yang baik dalam meningkatkan pemahaman publik. Terlebih informasi yang biasanya disampaikan oleh Kementerian Perdagangan adalah informasi yang berkaitan dengan bahasa ekonomi sehingga penggunaan infografis yang merupakan perpaduan antara beberapa komponen seperti teks, gambar, warna, 
Edy Juliyanto, Farid Rusdi: Strategi Penyampaian Informasi Melalui Instagram Dengan Tampilan Indografis (di Kementerian Perdagangan RI)

dan lain-lain. Dapat memudahkan publik dalam memahami isi informasi atau pesan yang disampaikan.

Ahli dan Praktisi media sosial Nukman Luthfie berpendapat bahwa penggunaan infografis oleh lembaga pemerintah merupakan hal yang tepat jika ingin menarik perhatian serta meningkatkan pemahaman anak muda terlebih pengguna media sosial kini kebanyakan para anak muda. Ahli media sosial ini menyatakan meme dan infografis kini merupakan medium yang banyak disukai oleh masyarakat sebab medium-medium itu dapat menggambarkan sesuatu yang rumit dengan cara yang sederhana.

Sementara menurut pengamat desain grafis Surianto Rustan, penggunaan infografis dapat meninggkatkan pemahaman atau pembelajaran terlebih di era digital ini masyarakat dibiasakan untuk melihat sesuatu yang berbau visual mulai dari icon pada gadget, emoji, sticker termasuk infografis. Akan tetapi Surianto menegaskan bila infografis yang hadir itu rumit atau kompleks akan kurang cocok bila diunggah ke media sosial.

Meskipun demikian, dengan adanya infografis yang dapat meningkatkan ketertarikan dan pemahaman publik medium yang lain dari Kementerian Perdagangan menjadi kurang diminati untuk dibaca. Seperti beberapa pengumuman yang tertera di situs daring Kementerian Perdagangan menjadi kurang dibaca oleh khalayak.

Hal ini dikonfirmasi oleh Kepala Subbagian Multimedia Biro Humas Kementerian Perdagangan, Rina Indriyana yang menyatakan dengan adanya infografis di akun Instagram Kementerian Perdagangan publik menjadi kurang tertarik untuk membaca teks atau dekskripsi yang panjang di situs daring Kementerian Perdagangan.

Analisis Penggunaan New Media: Media baru adalah revolusi pada ilmu komunikasi dan telah mengubah "keseimbangan kekuatan" dan media kepada khalayak, dalam hal mereka lebih memiliki pilihan untuk memilih dan lebih menggunakan media yang tersedia secara aktif. Komunikasi massa tradisional pada intinya bersifat satu arah, sementara bentuk baru komunikasi secara pokok adalah interaktif. Selain itu media baru juga memiliki dua aspek revolusioner yaitu digitalisasi dan konvergensi. Digitalisasi adalah proses dimana semua teks dapat dikurangi menjadi kode biner dan dapat mengalami proses produksi, distribusi dan penyimpanan yang sama. Konvergensi adalah penggabungan antara tulisan, suara ataupun gambar dari semua media tradisional dengan menggunakan sarana digital bila dibandingkan dengan media tradisional yang menggunakan sarana analog (McQuail, 2011:150).

Pemilihan media baru atau yang biasa dikenal dengan sebutan media sosial, kini dipilih oleh Kementerian Perdagangan RI untuk menyampaikan informasi yang berkaitan dengan kegiatan-kegiatan institusi. Beberapa saluran media baru yang digunakan oleh Kementerian Perdagangan RI untuk menyampaikan informasi antara lain Situs daring, Twitter, Facebook, saluran Youtube, dan juga Instagram. Alasan dipilihnya media baru sebagai saluran untuk menyampaikan informasi oleh Biro Humas Kementerian Perdagangan RI dijelaskan oleh Rina Indriyana karena saat ini memang media sosial terutama Instagram merupakan media sosial yang banyak digandrungi oleh masyarakat terutama anak-anak milenial, berbeda dengan media konvensional yang sudah kurang diminati oleh anak-anak milenial, ungkap Rina Indriyana. Rina Indriyana menjelaskan penyebaran informasi melalui Instagram banyak yang langsung berdampak kepada masyarakat terlebih, Instagram merupakan 
media sosial yang berfokus kepada media visual sehingga penyebaran infografis lebih tepat adanya di Instagram. Oleh karena beberapa alasan diatas dan saat ini Instagram sedang banyak digunakan oleh masyarakat, jadi Biro Humas Kementerian Perdagangan RI memaksimalkan penyampaian informasi dan diantaranya adalah Infografis melalui media sosial Instagram.

Nukman Luthfie sebagai Ahli dan Praktisi media sosial menjelaskan bahwa Twitter dan Instagram merupakan aplikasi yang berbasis informasi sehingga tidak perlu kenal masyarakat bisa mengikuti akun tersebut, tidak seperti Facebook yang berbasis pertemanan sebab penggunaan facebook harus disetujui dulu oleh penggunanya. Nukman juga menyatakan bahwa kini generasi muda sudah jarang menonton televisi dan membaca Koran. Kini sumber informasi yang paling dekat dengan masyarakat adalah media sosial, akan tetapi Nukman menghimbau kepada masyarakat sosial media itu bukan sumber informasi yang berbasis jurnalistik, jadi masyarakat harus hati-hati dalam memilih informasi mana yang bisa diambil dan mana yang harus dibuang.

Analisis Teknis Infografis: Infografis terdiri dari banyak komponen yang meningkatkan ketertarikan dan pemahaman bagi publik, diantaranya adalah gambar, ilustrasi, warna, jenis huruf, dan tipografi.

Infografis ada banyak jenisnya, angka, huruf dan tulisan juga bisa berperan sebagai gambar dan bisa sama kuat perannya dengan gambar atau ilustrasi.

Pemilihan warna pada infografis meningkatkan ketertarikan dan penerimaan pesan yang ingin disampaikan kepada khalayak. Ia menjelaskan kepada penulis sebuah penelitian yang menyatakan $90 \%$ orang memutuskan pilihannya berdasarkan warna, yang artinya warna merupakan komponen yang berpengaruh besar terhadap ketertarikan dan penyampaian pesan kepada khalayak.

Rancangan layout sebelum dibuatnya sebuah konten merupakan hal yang penting karena dalam sebuah medium pasti ada batasannya, jadi yang desainer tahu dimana batasan untuk membuat sebuah konten. Dan Surianto menegaskan bahwa "Layout adalah bentuk "negosiasi" desainer dengan media".

Form atau rupa dari sebuah medium disini yang dimaksudkan adalah infografis akan berpengaruh terhadap ketertarikan publik. Melihat bagaimana sang creator dalam mendesain tipografinya. Jadi, tipografi sangat signifikan perannya dalam menghadirkan form atau rupa dalam sebuah medium.

Menurut Surianto Rustan seorang ahli dan praktisi di bidang desain grafis, untuk meningkatkan pemahaman publik infografis sebaiknya dibuat sesederhana mungkin dan tidak rumit karena sebagai konten dalam media sosial Instagram harus diunggah dengan infografis yang sederhana agar publik mudah dalam mengerti isi dari informasi yang ingin disampaikan.

\section{Simpulan}

Penggunaan medium infografis merupakan hal yang tepat oleh peneliti dalam meningkatkan ketertarikan dan pemahaman publik. Sebab, untuk mengambil perhatian dari publik terutama para generasi muda yang saat ini memiliki minat baca yang rendah perlu dihadirkan satu langkah yang tepat salah satunya penyampaian informasi menggunakan medium infografis ini.

Peneliti menemukan kelemahan dari penggunaan infografis oleh Kementerian Perdagangan RI ini adalah masih banyaknya penggunaan bahasa atau istilah ekonomi yang kurang dipahami masyarakat luas. Hal ini menjadi sebuah kelemahan sebab 
penggunaan bahasa atau istilah ekonomi yang tercantum di dalam infografis Kementerian Perdagangan RI bisa menjadi berkurangnya pemahaman dari publik Kementerian Perdagangan RI.

Meskipun begitu, peneliti menyadari mengganti bahasa dan istilah lain dalam ranah ekonomi memang sulit dan mungkin tidak ada bahasa dan istilah lain yang secara tepat dapat menggantikan bahasa dan istilah ekonomi, tetapi itu addalah tantangan tersendiri bagi Kementerian Perdagangan. Jika Kementerian Perdagangan RI dapat menjelaskan keadaan dan situasi ekonomi dengan bahasa dan istilah yang umum dan dapat diterima oleh publik luas, pasti akan menghasilkan suatu pemahaman yang berbeda dan tentunya mengarah kepada hal yang lebih baik.

Untuk meningkatkan ketertarikan dan pemahaman publik, Kementerian Perdagangan RI dapat menghadirkan videografis sebagai medium baru dalam penyampaian pesannya. Terbukti generasi muda saat ini sering mengkonsumsi videovideo yang terdapat di aplikasi Youtube. Tidak perlu video animasi yang panjang, karna menurut pengamat media sosial Nukman Luthfie, tiga menit merupakan durasi ideal untuk para generasi muda menonton sebuah video.

\section{Ucapan Terima Kasih}

Ucapan terima kasih penulis berikan kepada Fakultas Ilmu Komunikasi Universitas Tarumanagara dan peneliti juga ingin berterima kasih kepada semua narasumber yang telah bersedia untuk meluangkan waktunya dan memberikan informasi kepada peneliti selama proses pengumpulan data dalam penelitian ini terutama Almarhum Nukman Luthfie yang telah memberikan pernyataan-pernyataan untuk melengkapi penelitian ini, semoga Almarhum ditempatkan di tempat yang terbaik di sisi Nya.

\section{Daftar Pustaka}

Ambrose, Gavin dan Harris, Paul. (2005). Basic Design: Layout. London: AVA Publishing.

Bungin, Burhan. (2011). Metodologi Penelitian Kualitatif. Jakarta: Kencana Predana Media.

Estrada, Sylvie. (2010). Graphic Design Project from Start to Finish. Spain: Dami Editorial and Printing Service Co.Ltd

Kusrianto, Adi. (2007). Pengantar Desain Komunikasi Visual. Yogyakarta: Andi Offset.

Lankow, J., Ritchie, J., Crooks, Ross. (2014). Infografis: Kedahsyatan Cara Bercerita Visual. Jakarta: Gramedia Pustaka Utama.

Mulyana, Deddy. (2001). Metodologi Penelitian Kualitatif Paradigma Baru Ilmu Komunikasi dan Ilmu Sosial Lainnya. Bandung: Remaja Rosdakarya.

McLuhan, M., Fiore, Q., Agel, J. (1996). The Medium is The Message: An Inventory of Effect. San Francisco: Hardwired

McQuail, D. (2011). Teori Komunikasi Mass. Jakarta: Salemba Humanika.

Sihombing, D. (2001). Tipografi Dalam Desain Grafis. Jakarta: Gramedia Pustaka Utama.

Sugiyono. (2011). Metode Penelitian Kualitatif dan R\&D. Bandung: Alfabeta. 